\title{
ANTIHYPERGLYCEMIC ACTIVITY OF TINOCRISPOSIDE BY STIMULATING 3T3-L1 ADIPOCYTE CELL DIFFERENTIATION
}

\section{ADEK ZAMRUD ADNAN ${ }^{1 *}$, MUHAMMAD TAHER ${ }^{2}$, ANNISA FAUZANA ${ }^{3}$, TIKA AFRIANI ${ }^{4}$, DEWI IMELDA ROESMA ${ }^{5}$, ANDANI EKA PUTRA ${ }^{6}$}

${ }^{1}$ Department of Pharmaceutical Chemistry, Faculty of Pharmacy, Andalas University, Padang, Indonesia. ${ }^{2}$ Department of Pharmaceutical Technology, Faculty of Pharmacy, International Islamic University Malaysia, 25200 Kuantan, Malaysia. ${ }^{3}$ Department of Pharmaceutical and Food Analyses, Universitas Abdurrab, Pekanbaru, 28293, Indonesia. ${ }^{4}$ Department of Pharmacy, Mohammad Natsir University, Bukittinggi

26136, Indonesia. ${ }^{5}$ Department of Biology, Andalas University, Indonesia. ${ }^{6}$ Department of Microbiology, Medicinal Faculty, Andalas, University, Indonesia. Email: adekzamrudadnan@phar.unand.ac.id

Received: 24 August 2018, Revised and Accepted: 15 October 2018

ABSTRACT

Objective: The aim of this study is to investigate the antihyperglycemic activity of tinocrisposide by stimulating 3T3-L1 adipocyte cell differentiation. Tinocrisposide is a furanoditerpene glycoside that was isolated from Tinospora crispa (Menispermaceae).

Methods: Adipocyte cell differentiation activity of tinocrisposide in interval concentrations of 50, 25, 12.5, and $6.25 \mu \mathrm{g} / \mathrm{ml}$ has been investigated on 3T3-L1 cell line using insulin of $1 \mu \mathrm{g} / \mathrm{ml}$ as a positive and Dulbecco's modified Eagle media (DMEM) as a negative control group. The effect of tinocrisposide was quantified with oil red 0 staining method by measuring an absorbance of lipid solution in isopropanol at a wavelength $(\lambda)$ of $520 \mathrm{~nm}$.

Results: Tinocrisposide in the concentrations of 50,25, 12.5, and $6.25 \mu \mathrm{g} / \mathrm{ml}$ insulin of $1 \mu \mathrm{g} / \mathrm{ml}$ and DMEM groups showed absorbance value of $0.7669,0.7253,0.6563,0.6481,0.954$, and 0.2653 , respectively. It was found that there was a significant difference statistically in lipid droplets accumulation among all groups ( $\mathrm{p}<0.05$ ) and tinocrisposide at a concentration of $50 \mu \mathrm{g} / \mathrm{ml}$ showed the highest lipid droplets accumulation in 3T3-L1 adipocyte cells.

Conclusion: From the study, it could be concluded that tinocrisposide was able to stimulate the differentiation of adipocyte cell and had antihyperglycemic activity.

Keywords: 3T3-L1 adipocyte cell differentiation, Antihyperglycemic, Tinocrisposide, Tinospora crispa.

(c) 2018 The Authors. Published by Innovare Academic Sciences Pvt Ltd. This is an open access article under the CC BY license (http://creativecommons. org/licenses/by/4. 0/) DOI: http://dx.doi.org/10.22159/ajpcr.2018.v11i11.29304

\section{INTRODUCTION}

The incidence of diabetes mellitus (DM) case is increasing tremendously in most part of the world, especially in developing countries. This disease causes substantial morbidity, mortality, and long-term complications such as retinopathy, neuropathy, and nephropathy [1]. DM is a chronic metabolic disorder characterized by hyperglycemia resulting from defects in insulin secretion, insulin action, or both. It is well documented that chronic hyperglycemia of diabetes is associated with a series of pathological changes, tissue damages, and eventually leads to the failure of organ function. The target organs and tissues include the eyes, kidneys, nerves, heart, and blood vessels [2].

Medicinal plants are very important resources for drug candidates and were targeted for finding new drugs to treat various medical conditions. Medicinal plants have an advantage as drugs resources because they contain relatively high bioactive compound [3]. Tinospora crispa (L.) Miers Hook f. and Thoms (Menispermaceae) is a climbing plant that found in the tropic and subtropical region of Asia, such as Indonesia, Malaysia, Thailand, and India, and for a long time, it has been used traditionally as antidiabetic drugs.

Ethanol extract of T. crispa has an effect to decrease blood glucose concentration on experimental diabetic rats. This hypoglycemic effect was likely due to by insulinotropic mechanism [2]. From methanol extract of dried pulverized T. crispa stems, tinocrisposide $\left(\mathrm{C}_{27} \mathrm{H}_{36} \mathrm{O}_{11}\right)$ has been isolated, a furanoditerpene glycoside with a very bitter taste [4]. It is considered that tinocrisposide is responsible for some biological activity of T. crispa stem extracts so that it has been used as an antidiabetic treatment in traditional medicine (Fig. 1).

In a previous study, we have investigated the effect of tinocrisposide in lowering of blood glucose level on alloxan-induced hyperglycemic mice [5]. Adipocyte cells have a function as a blood glucose level regulation, therefore it can be as one of antihyperglycemic drugs target. Differentiated adipocyte cells are sensitive to insulin because exposure to insulin increases the number of insulin's receptor on its cell membrane. In the present study, an antihyperglycemic activity of tinocrisposide has been discovered in vitro using 3T3-L1 adipocyte cell and its results will be reported in this article.

\section{MATERIALS AND METHODS}

Materials

Mice 3T3-L1 preadipocyte, obtained from ATCC (Rockville, MD, USA), were grown in Dulbecco's modified Eagle's medium (DMEM) Gibco (Paisley, UK) supplemented with $10 \%$ bovine calf serum Gibco (Paisley, UK), and antibiotics $(100 \mathrm{U} / \mathrm{ml}$ penicillin and $100 \mu \mathrm{g} / \mathrm{ml}$ streptomycin) Gibco (Paisley, UK) at $37^{\circ} \mathrm{C}$ under a humidified $5 \% \mathrm{CO}_{2}$ atmosphere. Cells were subcultured every 3-4 days at approximately $80 \%$ confluence.

\section{Instruments}

Class II biological safety cabinet (Jouan MSC 12, Thermo Fisher Scientific, USA), Hemocytometer (Hirschmann, EM Techcolor, Germany), Inverted Microscope (TC 5400, Meiji Techno, Japan), Hemocytometer 
(Hirschmann, EM Techcolor, Germany), Microplate reader (Dynatech MR5000 TECAN, Tecan Group Ltd., Switzerland), (Thermo Fisher Scientific, USA), Autoclave (HV-85, Hirayama, Japan), CO2 Incubator (NU-5100E, Nuaire, USA), and Light microscope (Motic B2 series, Motic Asia, Hongkong) were used.

\section{Experimental procedure}

\section{Cell viability assay}

Cell viability was assessed by 3-(4,5-dimethylthiazol-2-yl)-2,5diphenyltetrazolium bromide (MTT) assay as described by Parimala et al., 2015. Mature adipocyte cells were seeded in 96-well plates and grown until $80-90 \%$ confluence. Tinocrisposide was dissolved in dimethylsulfoxide (DMSO) to get the solutions in concentrations interval from 3.125 to $100 \mu \mathrm{g} / \mathrm{ml}$ (Table 1). Our preliminary study showed that DMSO at a concentration of $<0.1 \%$ in media did not affect cell viability or differentiation. Each concentration of tinocrisposide was added to mature adipocytes in 96-well plates and incubated for $2 \mathrm{~h}$ at $37^{\circ} \mathrm{C}$. Cells were then washed 2 times with phosphate buffer saline (PBS) and $10 \mu \mathrm{l}$ of MTT stock solution $(5 \mathrm{mg} / \mathrm{ml})$ was added to each well and the plates were further incubated for $4 \mathrm{~h}$ at $37^{\circ} \mathrm{C}$ under $5 \% \mathrm{CO}_{2}$ atmosphere. Then, the supernatant was discarded and $200 \mu \mathrm{l}$ of DMSO was added to each well to solubilize the water insoluble formed purple formazan crystals, and the solutions were stored at room temperature in the dark place.

After $1 \mathrm{~h}$, the absorbance was measured at a wavelength of $550 \mathrm{~nm}$ and a reference wavelength of $630 \mathrm{~nm}$ with a microplate reader. Cell viability was calculated then according to the following equation.

$\%$ Viability $=[($ A treated group - A medium $) /($ A untreated - A medium $)]$ $\times 100 \%$

\section{Adipocyte cell differentiation}

Cells were seeded into 4 -well plates at a density of $2 \times 104$ cells/ well. 2 days after experiment cells became confluence (defined as day-0), cells were stimulated gently to differentiate with a medium containing DMEM, 10\% fetal bovine serum (FBS), and MDI $(0.5 \mathrm{mM}$ 3-isobutyl-1-methylxanthine [IBMX], $0.25 \mu \mathrm{M}$ dexamethasone, and $1 \mu \mathrm{g} / \mathrm{ml}$ insulin) for 2 days. In the course of screening adipocyte differentiation-stimulated activity, 3T3-L1 preadipocyte was treated

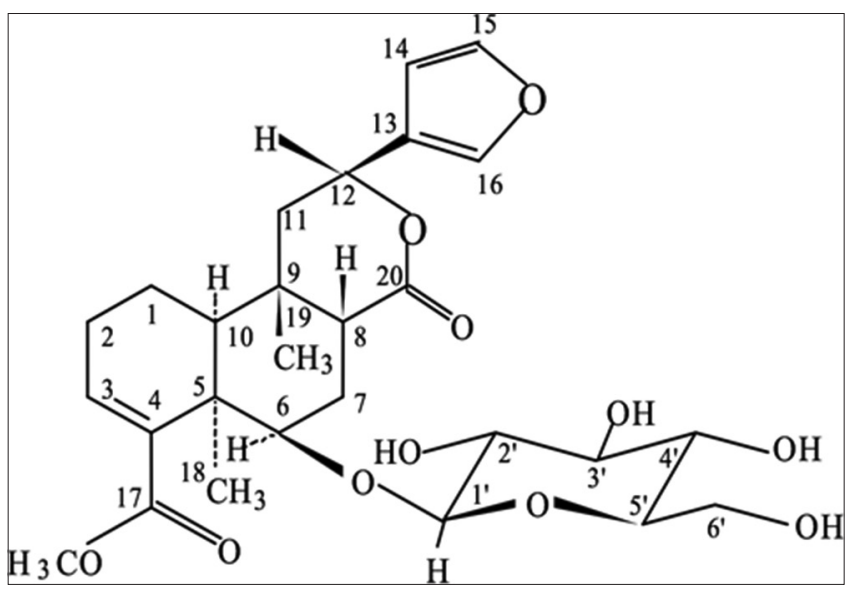

Fig. 1: Chemical structure of tinocrisposide [4] with differentiation medium in the presence of various concentrations of tinocrisposide $(6.25,12.5,25$, and $50 \mu \mathrm{g} / \mathrm{ml})$ at day-0 (Table 1).

Concentrations of tinocrisposide were selected based on toxicity assay, where the concentration of 6.25 and $50 \mu \mathrm{g} / \mathrm{ml}$ showed viability adipocyte cells of $72.8492 \%$ and $61.8871 \%$, respectively (as presented in Table 2). At day-2, differentiating medium was replaced with the mixture 10\% FBS and DMEM medium containing $1 \mu \mathrm{g} / \mathrm{mL}$ insulin and incubated properly for another 2 days (day-4). Thereafter, the cells were maintained in 10\% FBS/DMEM medium for an additional 4 days (day-8) with medium changes every 2 days [7]

\section{Oil red 0 staining}

8 days after the differentiation induction, mature adipocyte cells were washed 3 times with PBS and fixed with $10 \%$ formalin for $1 \mathrm{~h}$ at room temperature. After fixation, cells were washed directly once used PBS and stained immediately with freshly diluted oil red O-solution (three parts of $0.6 \%$ oil red 0 in isopropanol and two parts of distilled water) for $1 \mathrm{~h}$. Cells were then washed twice with distilled water and visualized under a microscope. All experiment images were taken and collected by an Olympus (Tokyo, Japan) microscope.

\section{Quantitative analysis of oil red 0 staining}

Oil red O-stain was dissolved with isopropanol and optical density was measured at $520 \mathrm{~nm}$ by enzyme-linked immunosorbent assay plate reader [7]

\section{Oil red 0 staining process}

After differentiation, the cells were fixed for $1 \mathrm{~h}$ at room temperature with $10 \%$ formalin in PBS, washed 3 times with PBS, and then stained for $1 \mathrm{~h}$ with filtered oil red $\mathrm{O}$ ( $0.5 \%$ in $60 \%$ isopropanol). After the cells were washed 3 times with distilled water, the cells were photographed under a microscope. Lipid and oil red 0 were extracted using isopropanol, and absorbance was measured using a spectrophotometer at a wavelength of $520 \mathrm{~nm}$ [6].

\section{RESULTS AND DISCUSSION}

Effect of tinocrisposide on the viability of 3T3-L1 adipocyte cells The viability assay was used to determine any possible toxicity effect of tinocrisposide on the cells. Mature adipocyte cells were treated with various tinocrisposide concentrations. The viability of cell was quantified with MTT method by measuring the absorbance of a formed formazan solution at $\lambda 550 \mathrm{~nm}$ with a microplate reader (Table 2).

Data in Table 2 showed that treatment 3T3-L1 adipocyte cells with tinocrisposide in concentration level of $3.125,6.25,12.5,25,50$, and $100 \mu \mathrm{g} / \mathrm{ml}$ exerted the cell viability of $88.9916,72.8492,69.2414$, 65.5411, 61.8871, and 56.7992\%, respectively. High concentration of tinocrisposide can exert the toxicity effect on adipocyte cells; therefore, tinocrisposide was used in following adipocyte differentiation assay in the concentration levels of $3.125-50 \mu \mathrm{g} / \mathrm{ml}$. The $\mathrm{IC}_{50}$ of tinocrisposide toward adipocyte cell 3T3-L1 was calculated by regression equation and it found to be at $102.29 \mu \mathrm{g} / \mathrm{ml}$. It can be concluded that tinocrisposide has low toxicity toward 3T3-L1 adipocyte cell $\left(\mathrm{IC}_{50} \geq 100 \mu \mathrm{g} / \mathrm{ml}\right)$.

\section{Tinocrisposide effect on adipocyte cell differentiation}

Intracellular triglyceride droplets which indicate that adipocyte cell begins to differentiate were observed at day- 4 of differentiation. In the

Table 1: Differentiation scheme of adipocyte cells

\begin{tabular}{llll}
\hline Day & Negative control & Positive control & Treatment group \\
\hline 0 & No inducer (DMEM) & Dexamethasone $(0.25 \mu \mathrm{M})$ & Dexamethasone $(0.25 \mu \mathrm{M})$ \\
& & IBMX $(0.5 \mathrm{mM})$ & IBMX $(0.5 \mathrm{mM})$ \\
& & Tinocrisposide $(6.25,12.5,25$, and $50 \mu \mathrm{g} / \mathrm{ml})$ \\
2 & No inducer $(\mathrm{DMEM})$ & Insulin $(100 \mathrm{nM})$ & Insulin $(100 \mathrm{nM})$ \\
& Complete medium & Complete medium & Complete medium \\
\hline
\end{tabular}


following day, the number and the diameter of triglyceride droplets increased. 8 days after treatment, preadipocyte differentiation was terminated and stained with oil red 0 . Triglyceride droplets in these cells were visualized and photographed (Fig. 2).

Tinocrisposide increases intracellular lipid accumulation in 3T3$\mathrm{L} 1$ adipocyte cell

Quantification of lipid accumulation of negative control group (DMEM), IBMX-dexamethasone group, and tinocrisposide with various concentrations $(6.25,12.5,25$, and $50 \mu \mathrm{g} / \mathrm{ml})$ and positive control group (insulin $1 \mu \mathrm{g} / \mathrm{ml}$ ) using spectrophotometer at $\lambda 520 \mathrm{~nm}$ showed absorbance of $0.2653,0.4043,0.6481,0.6563,0.7253,0.7669$, and 0.9504 , respectively (Table 3 and Fig. 2). Absorbance data were processed by statistical method to determine the statistical difference among the groups $(\mathrm{p}<0.05)$

The data in Table 3 showed that absorbance of tinocrisposide of all treatment doses was higher and significantly different then absorbance of IBMX-dexamethasone group $(\mathrm{p}<0.05)$ which means that tinocrisposide stimulated the adipocyte cell differentiation in a dosedependent manner. The tinocrisposide showed maximum adipogenic activity at a dose of $50.0 \mu \mathrm{g} / \mathrm{ml}$ and had stimulating activity at $189 \%$ relative to MDI-treated control cells and $80.6 \%$ relative to positive control group (insulin $1 \mu \mathrm{g} / \mathrm{ml}$ ). It could be concluded from this study that tinocrisposide could stimulate adipocyte differentiation, but it is not as strong as the stimulation caused by insulin $(1 \mu \mathrm{g} / \mathrm{ml})$. Data on tinocrisposide concentrations and formed triglyceride solution absorbance at $\lambda 520 \mathrm{~nm}$ were processed by Microsoft Excel Software as shown in Fig. 3 .

A linear correlation $(R=0.9643)$ was found between the concentration of treated tinocrisposide and the formed triglyceride solution absorbance. This finding supported the evidence that tinocrisposide has an adipogenic activity in a concentration-dependent manner.

Adipocyte plays a key role in the control of systemic glucose and lipid homeostatic $[8,9]$. Glucose uptake will increase adipocyte cell

Table 2: Effect of tinocrisposide on 3T3-L1 adipocyte cell viability

\begin{tabular}{lll}
\hline $\begin{array}{l}\text { Tinocrisposide } \\
\text { concentrations }(\boldsymbol{\mu g} / \mathbf{m l})\end{array}$ & $\begin{array}{l}\text { Average } \\
\text { absorbance }\end{array}$ & \% viability \\
\hline 100 & $0.0978 \pm 0.00462$ & 56.7992 \\
50 & $0.1015 \pm 0.00123$ & 61.8871 \\
25 & $0.1041 \pm 0.00326$ & 65.5411 \\
12.5 & $0.1068 \pm 0.00163$ & 69.2414 \\
6.25 & $0.1094 \pm 0.00446$ & 72.8492 \\
3.125 & $0.1210 \pm 0.00683$ & 88.9916 \\
0 & $0.1289 \pm 0.00965$ & 100 \\
\hline
\end{tabular}

differentiation. Differentiated adipocyte cell is more responsive to the hormones that play a role in the regulation of glucose metabolism [10]. One of the hormones that very important in adipocyte cells differentiation is insulin, which stimulates glucose uptake in differentiated adipocyte cells [11,12]. Adipocyte was recognized as central players in the pathogenesis of insulin resistance. Adipocyte acts as free fatty acid (FFA) storage depot [13] and increasing the capacity of adipocyte to store FFA leads to insulin resistance [14]. Adipocytes secret multiple hormones and cytokines which directly regulate body insulin sensitivity $[13,15]$

Differentiation of adipocyte cells will follow by promoting of insulin sensitivity $[9,16]$. During the terminal phase of differentiation, activation of a transcriptional cascade leads to increasing glucose transporter and insulin receptor [16]. Insulin will phosphorylate insulin receptors (IRs) that are followed by phosphorylation process of receptors substrate (IRS)-1 and IRS-2 that leads to the activation of phosphoinositide 3-kinase (IP3K) signaling. IP3K activating provides the translocation of glucose transporter-4 (GLUT-4) from vesicle in sitosol toward cell membrane to facilitate glucose uptake into adipocyte cells [9].

Inability of adipocyte cell to differentiate is one of the pathological factors of some metabolic diseases such as diabetes $[6,17]$. In our study, tinocrisposide stimulated adipocyte differentiation that increased its insulin sensitivity. Various concentrations of tinocrisposide showed higher adipocyte cell 3T3-L1 differentiation then negative control DMEM and MD $(\mathrm{p}<0,05)$. The stimulating effect of tinocrisposide on adipocyte cell differentiation was higher than MD but slightly lower than the positive control (insulin). Meanwhile, Saraphanchotiwitthaya and Sripalakit determined the in vitro antiobesity effects of Morinda citrifolia leaf extract and herbal formulas used traditionally for weight loss in Thailand on lipid accumulation in 3T3-L1 adipocytes [18].

Adipocyte cells differentiation is a multistep process involving a cascade of transcription factors [13] and cell-cycle proteins regulating gene expression and leading to adipocyte development [19]. Some proteins that expressed in differentiated adipocyte cells were CCAAT/ enhancer-binding protein (C/EBP) $\alpha$ and peroxisome proliferator-

Table 3: Absorbance of cellular triglyceride solutions at 520 nm

\begin{tabular}{ll}
\hline Treated group & Absorbance \\
\hline Negative control group (DMEM) & 0.2653 \\
IBMX-dexamethasone group & 0.4043 \\
Tinocrisposide $6.25 \mu \mathrm{g} / \mathrm{ml}$ & 0.6481 \\
Tinocrisposide $12.5 \mu \mathrm{g} / \mathrm{ml}$ & 0.6563 \\
Tinocrisposide $25.0 \mu \mathrm{g} / \mathrm{ml}$ & 0.7253 \\
Tinocrisposide $50.0 \mu \mathrm{g} / \mathrm{ml}$ & 0.7669 \\
Positive control group (insulin $1 \mu \mathrm{g} / \mathrm{ml})$ & 0.9504 \\
\hline
\end{tabular}

DMEM: Dulbecco's Modified Eagle media

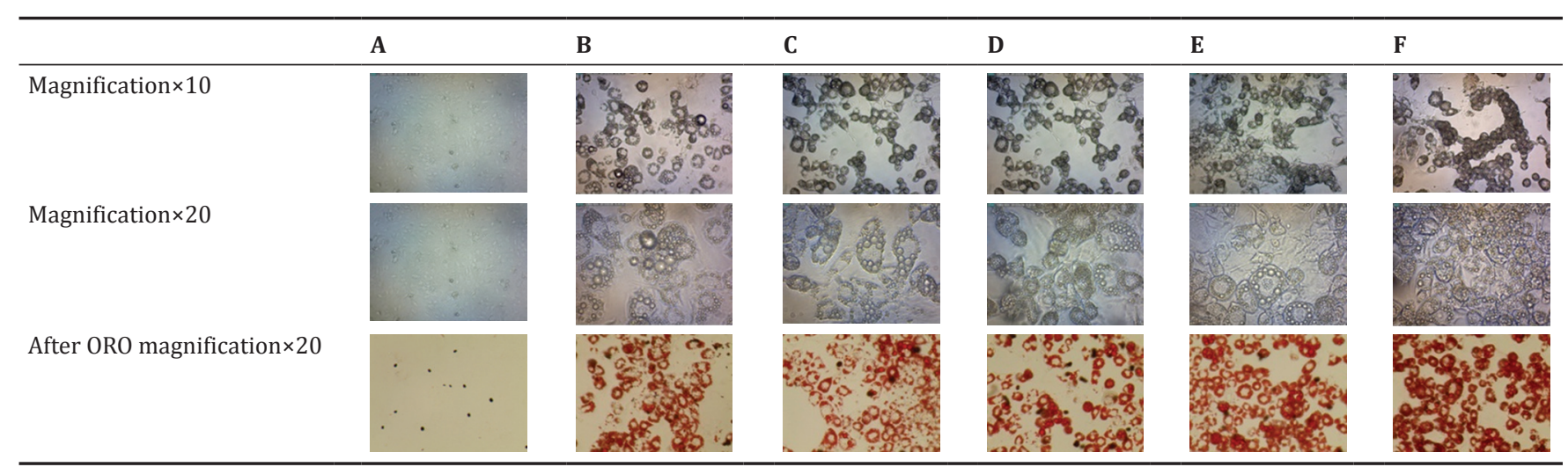

Fig. 2: Adipocyte cell morphology on day-8, before and after ORO staining, (a) negative control, (b) tinocrisposide $6.25 \mu \mathrm{g} / \mathrm{ml}$, (c) tinocrisposide $12.5 \mu \mathrm{g} / \mathrm{ml}$, (d) tinocrisposide $25 \mu \mathrm{g} / \mathrm{ml}$, (e) tinocrisposide $50 \mu \mathrm{g} / \mathrm{ml}$, (f) positive control (insulin $100 \mathrm{nM}$ ) 


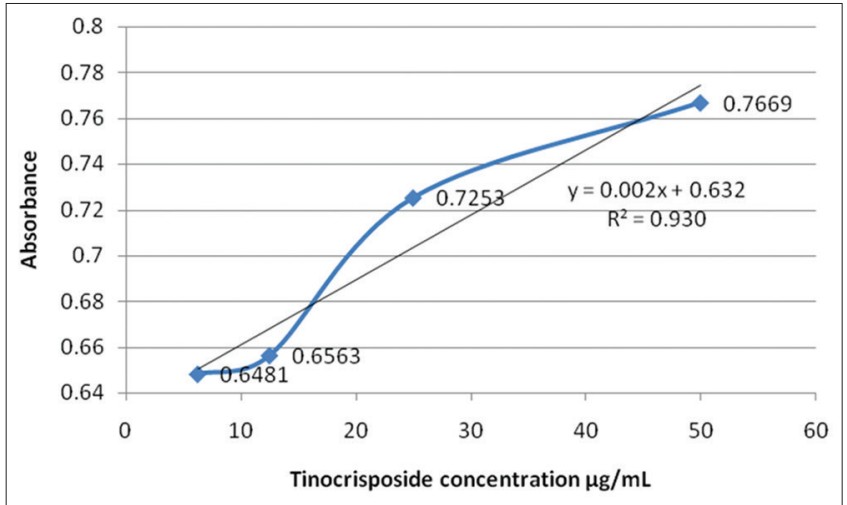

Fig. 3: Tinocrisposide concentration versus absorbance

activated receptor (PPAR $\gamma$ ) [20]. C/EBP $\alpha$ [21] and PPAR $\gamma$ have a function as a regulation master of adipocyte cell differentiation $[7,22]$. $\mathrm{C} / \mathrm{EBP} \alpha$ induces many adipocyte genes directly during differentiation, such as 442 (aP2) [23] and stearoyl-CoA desaturation I (SCD1), that has a function in fat metabolism and so that blood fatty acid level can be reduced [24,25]. PPAR $\gamma$ is a master regulator of adipogenesis [15] and its expression will increase the expression of 442 (aP2) [22], SCD1, IR, IRS-2, and GLUT-4. It will increase uptake of the FFA and store it in the form of triglyceride molecule; furthermore, it will increase uptake of glucose into adipocyte cell [9].

Adipocyte cells fail to express of C/EBP $\alpha$ and PPAR $\gamma$ lead to failure of adipocyte cell differentiation and it was followed by insulin resistance [21]. At present, available full PPAR $\gamma$ agonists represented by thiazolidinediones (e.g., pioglitazone) are clinically effective, but they have a serious side and off-target effects (e.g., weight gain or edema formation), urging the retrieval of new PPAR $\gamma$ agonists [26]. Tinocrisposide might have stimulated the adipocyte cell differentiation by promoting the expression of C/EBP $\alpha$ and PPAR $\gamma$. Expression increasing of C/EBP $\alpha$ and PPAR $\gamma$ by tinocrisposide will raise the protein expression of 442 (aP2) [22], SCD 1, IRS-2, IR, and GLUT-4 that increases FFA and glucose uptake into adipocyte cell that follows by enhancing insulin sensitivity which provides the antihyperglycemic effect of tinocrisposide. The research should be continued with the gene expression analysis as described by Sitepu et al. [27] and gene expression that might be affected by tinocrisposide could be investigated.

\section{CONCLUSION}

Tinocrisposide stimulated the 3T3-L1 adipocyte cell differentiation. Adipocyte cell differentiation activity of tinocrisposide was found much higher than negative control and MD groups but slightly lower than insulin. We believed that the antihyperglycemic effect of tinocrisposide was realized by its capability to stimulate adipocyte differentiation which in the end will increase the adipocyte insulin sensitivity, thus enhancing the adipocyte FFA and glucose uptake.

\section{ACKNOWLEDGMENT}

The authors would like to thank Andalas University, Padang, Indonesia, for the grant given for this research.

\section{AUTHORS' CONTRIBUTIONS}

Conception and design of study: A.Z. Adnan, M. Taher, and A. Fauzana. Acquisition of data: M. Taher, A. Fauzana, and T. Afriani. Analysis an interpretation of data: A.Z. Adnan, M. Taher, and A. Fauzana. Drafting the manuscript: T. Afriani, A. Fauzana, D.I. Roesma, and A.E. Putra. Revising the manuscript critically for important intellectual content: A.Z. Adnan, M. Taher, and A. Fauzana.

\section{CONFLICTS OF INTEREST}

The authors declare that they have no conflicts of interest.

\section{REFERENCES}

1. Talubmook C, Buddhakala N. Bioactivities of extracts from Tinospora crispa stem, Annona squamosa leave, Musa sapientum flower, and Piper sarmentosum leave in diabetic rats. Int J Adv Res Technol 2013;2:144-9.

2. Ruan X, Zheng F, Guan Y. A review: PPARs and the kidney in metabolic syndrome. Am J Physiol Renal Physiol 2008;298:1032-47.

3. Rafter JJ. Scientific basis of biomarkers and benefits of functional foods for reduction of disease risk: Cancer. Br J Nutr 2002;88 Suppl 2:S219-24.

4. Pachaly P, Adnan AZ. Tinocrisposid, ein neues furanoditerpenglykosid aus Tinospora crispa Miers. Arch Pharm (Weinheim) 1992;325:705-8.

5. Adnan AZ, Ruslan R, Sari SI. Study of the Antihyperglycaemic Effect of Tinocrisposide on Aloxan Induced Mice. Nagoya Sakae Tokyu REI Hotel Nagoya, Nagoya, Japan: Proceeding of the International Conference on Advancing the Life Sciences and Public Health Awareness; 2016.

6. Choi JS, Kim JH, Ali MY, Min BS, Kim GD, Jung HA, et al. Coptis chinensis alkaloids exert anti-adipogenic activity on 3T3-L1 adipocytes by down regulating C/EBP- $\alpha$ and PPAR- $\gamma$. Fitoterapia 2014;98:199-208.

7. Choi SS, Cha BY, Lee YS, Yonezawa T, Teruya T, Nagai K, et al. Magnolol enhances adipocyte differentiation and glucose uptake in 3T3-L1 cells. Life Sci 2009;84:908-14.

8. Christodoulides C, Vidal-Puig A. PPARs and adipocyte function. Mol Cell Endocrinol 2010;318:61-8.

9. Tamori Y, Masugi J, Nishino N, Kasuga M. Role of peroxisome proliferator-activated receptor-gamma in maintenance of the characteristics of mature 3T3-L1 adipocytes. Diabetes 2002;51:2045-55.

10. Biasiotto G, Zanella I, Masserdotti A, Pedrazzani R, Papa M, Caimi L, et al. Municipal wastewater affects adipose deposition in male mice and increases 3T3-L1 cell differentiation. Toxicol Appl Pharmacol 2016;297:32-40.

11. Hahm JR, Noh HS, Ha JH, Roh GS, Kim DR. Alpha-lipoic acid attenuates adipocyte differentiation and lipid accumulation in 3T3L1 cells via AMPK-dependent autophagy. Life Sci 2014;100:125-32.

12. Reed BC, Lane MD. Insulin receptor synthesis and turnover in differentiating 3T3-L1 preadipocytes. Proc Natl Acad Sci U S A 1980;77:285-9.

13. Jang H, Kim HJ, Kim DH, Park JK, Sun WS, Hwang S, et al. Small heterodimer partner-interacting leucine zipper protein inhibits adipogenesis by regulating peroxisome proliferator-activated receptor $\gamma$ activity. Life Sci 2015;132:49-54

14. Savage DB, Petersen KF, Shulman GI. Mechanisms of insulin resistance in humans and possible links with inflammation. Hypertension 2005; $45: 828-33$.

15. Rosen ED, Hsu CH, Wang X, Sakai S, Freeman MW, Gonzalez FJ, et al. C/EBPalpha induces adipogenesis through PPARgamma: A unified pathway. Genes Dev 2002;16:22-6.

16. Moreno-Navarrete J, Fernande-Real JM. Adipocyte differentiation. Adipose Tissue Biol 2012;6:17-38.

17. Ntambi JM, Young-Cheul K. Adipocyte differentiation and gene expression. J Nutr 2000;130:3122S-6S.

18. Saraphanchotiwitthaya A, Sripalakit P. Inhibition of lipid accumulation in 3T3-L1 adipocytes by Morinda citrifolia Linn. Leaf extracts and commercial herbal formulas for weight control. Int J Pharm Pharm Sci 2016;8:199-204.

19. Lefterova MI, Lazar MA. New developments in adipogenesis. Trends Endocrinol Metab 2009;20:107-14.

20. Zebisch K, Voigt V, Wabitsch M, Brandsch M. Protocol for effective differentiation of 3T3-L1 cells to adipocytes. Anal Biochem 2012;425:88-90.

21. Farmer SR. Transcriptional control of adipocyte formation. Cell Metab 2006; 4:263-73.

22. Jeong YJ, Sohn EH, Jung YH, Yoon WJ, Cho YM, Kim I, et al. Antiobesity effect of Crinum asiaticum var. Japonicum baker extract in highfat diet-induced and monogenic obese mice. Biomed Pharmacother 2016;82:35-43.

23. Choi JW, Lee CW, Lee J, Choi DJ, Sohng JK, Park YI, et al. 7,8-dihydroxyflavone inhibits adipocyte differentiation via antioxidant activity and induces apoptosis in 3T3-L1 preadipocyte cells. Life Sci 2016;144:103-12.

24. Christy RJ, Yang VW, Ntambi JM, Geiman DE, Landschulz WH, Friedman AD, et al. Differentiation-induced gene expression in 3T3L1 preadipocytes: CCAAT/enhancer binding protein interacts with and activates the promoters of two adipocyte-specific genes. Genes Dev 1989;3:1323-35.

25. Kajimura S, Seale P, Tomaru T, Erdjument-Bromage H, Cooper MP, Ruas JL, et al. Regulation of the brown and white fat gene programs 
through a PRDM16/CtBP transcriptional complex. Genes Dev 2008;22:1397-409.

26. Atanasov AG, Wang JN, Gu SP, Bu J, Kramer MP, Baumgartner L, et al. Honokiol: A non-adipogenic PPAR $\gamma$ agonist from nature. Biochim
Biophys Acta 2013;1830:4813-9.

27. Sitepu R, Retnoningrum DS, Tjandrawinata RR. Molecular analysis og gene expression related to the effects of DLBS3233 treatment in differentiation of 3T3-L1 pre-adipocyte. Int J Pharm Pharm Sci 2016;8:350-5 